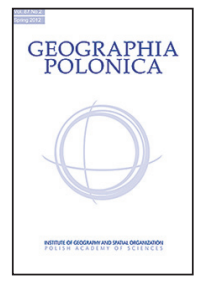

\title{
SPATIAL CONCENTRATION OF FOREIGN OWNED ENTITIES IN POLAND
}

\author{
Jarosław Michał Nazarczuk • Anna Krajewska \\ Faculty of Economic Sciences, Department of Economic and Regional Policy \\ University of Warmia and Mazury in Olsztyn \\ Oczapowskiego 4, 10-719 Olsztyn: Poland \\ e-mails: jaroslaw.nazarczuk@uwm.edu.pl • a.krajewska@uwm.edu.pl
}

\begin{abstract}
Foreign direct investment plays a crucial role in global capital and trade flows. The FDI's influence on national, regional and local economies is often the subject of public political and economic discussion, as well as numerous incentives to acquire foreign capital. The aim of this article is to identify the spatial concentration of firms with foreign capital (FOEs) in Poland at the municipality/gmina level (LAU 2) between 1995 and 2017 as well as the determinants of their location. With the use of I Moran's statistics and spatial probit models, the intensity of the FDI location as well as their location determinants were verified. The authors also indicate the areas of spatial concentration and potential areas of positive externalities resulting from FOEs agglomeration.
\end{abstract}

\section{Key words}

location - agglomeration - cities - foreign direct investment $-\mathrm{FDI} \cdot$ determinants $\bullet$ spatial autocorrelation

\section{Introduction}

The spatial analyses of direct foreign investment (FDI) or foreign owned entities (FOEs) in hosting economies became more frequent after the emergence of New Economic Geography (NEG) which gave researchers the theoretical foundations for quantitative studies in space. The main message of the new economic geography involves distinguishing between first and second order geographical factors. The former refers to the existing equipment of the economy in natural resourc- es, geographic location, climate, soil quality, elevation, etc. These are primarily exogenous factors. According to the neo-classical approach, in the absence of external effects, there are no drivers of agglomeration economies. Umiński (2012) indicates that if the economic activity is dispersed evenly in space, its shape is primarily determined by factors of an exogenous nature (so-called first-order factors).

The new economic geography describes the importance of the so-called second nature factors. These factors, according to Ottaviano 
and Thisse (2005), are the result of human activity, the primary objective of which is to improve the factors resulting from the first order. The new economic geography, therefore, answers the question of the extent to which second-order factors explain this part of the spatial distribution of FDI, which cannot be described by first-order factors (advantages resulting from natural conditions).

According to Cieślik (2007), the spatial concentration of FDI activity is weakly correlated with investment incentives offered by the government, which encourage investors to establish its plants in less attractive parts of Poland. It is, however, noted that the activity of FDI is concentrated in some of the best-developed regions of the country. The geographic concentration of economic activity is the result of the existence of various advantages of the agglomeration as well as many other factors which influence the location decisions made by the companies (Fujita \& Thisse 2013).

Regions differ in terms of economic size, therefore, due to the choices made by investors, more foreign-owned companies are located in larger regions (often better equipped with resources, having superior infrastructure, offering larger markets, etc.). In fact, market size, usually proxied by GDP per capita or GDP, is one of the most robust FDI determinants (Resmini 2007). It's of prime significance in the case of service FDI (Resmini 2013). Similarly, on the list of important locational criteria are: factor endowment, agglomeration among FDI, infrastructure.

According to Latocha (2002), investors establish their new businesses in well-developed economic regions, which are urbanindustrial centres (the so-called growth poles). Taking into an account the economic value of the region, it is possible to conclude that the majority of companies with foreign capital are concentrated in regions along the western border of Poland. These regions are very attractive to foreign investors who want to minimize their operating costs because a large part of their production is sold abroad (Cieślik 2007).
Most of the available regional analyses of FDI location in Poland is conducted at the voivodship level (NUTS 2), depicting different aspects of factors affecting FDI concentration (border effects, location of special economic zones, size of firms, industry location, locational factors, etc.) (Domański 2001; Cieślik 2005a, 2005b, 2005c, 2007, 2013; Cieślik \& Ryan 2005; Chidlow et al. 2009). However, due to the high intraregional inequalities observed in Poland (OECD 2010; Nazarczuk 2013; Nazarczuk 2015) the differences at a lower level of aggregation of data in the above analyses remain unknown. An example of such internal differences may be the spatial agglomeration of FDI location, which is the subject of this work.

One of the notable exceptions from the above-mentioned rule is the work of Zdanowska (2017), who analysed FDI linkages with urban systems in CEECs. However, the degree of spatial agglomeration, together with possible externalities, remained unknown in the paper. Kisiel et al. (2017) have analysed the role of distance to regional capitals as a factor of FDI location, whereas Nazarczuk and Krajewska (2018) have investigated subregional (LAU 1) FDI locational determinants with the use of econometric panel methods.

The article aims to identify: (I) the spatial concentration of companies with foreign capital in Poland at the municipality/gmina level (LAU 2) in the years 1995-2017, as well as (II) locational criteria of FOEs. Using the statistics of spatial autocorrelation, i.e. the local and global measures of I Moran's statistics, the paper reveals the hubs of high FOEs concentration, whereas estimation of spatial probit models, have enabled the identification of FOEs locational criteria.

\section{Theoretical concepts agglomeration}

The benefits of the agglomeration are one of the crucial factors for attracting investment in the region. The empirical and theoretical literature mainly focuses on the effect 
of agglomerations as a determinant of firms/ FDI locations (Marshall 1920; Hoover 1936; Arrow 1962; Jacobs 1969; Krugman 1991; Audretsch 1998; Fujita et al. 2001; Crozet et al. 2004; Bronzini 2007; Du et al. 2008; Ottaviano 2011). According to Marshall (1920), there are three main sources of FDI attractiveness: an affluent labour market, resulting from economic specialisation, the ease of finding a company producing a specific good or providing a specific service within a cooperative relationship, and lastly, rapid and efficient dissemination of information. The study of Casi \& Resmini (2014) provides evidence for the role of region-based factors (e.g. access to EU-markets, quality and price of labour, local institutions) as well as countrybased (country's performance in absorbing $\mathrm{FDI}$ ), that are of prime interest among FOEs. However, given the character of the criteria, regional/local factors are more important than national ones.

FDI may have a stimulant role in improving regional productivity in indigenous sectors (both within and across sectors) (Nicolini \& Resmini 2011b), due to the technology transfer in FDI-induced spillovers. Thus, potential externalities generated by FDI, like the surge in firms' or industries' performance (Roubíčková \& Heryán 2014), may be limited to areas abundant in FDls. The scope of their influence is to a large extend conditioned on the quality of local social capital, which can hamper or stimulate FDI-induced spillovers to the regional economy (Casi \& Resmini 2017). These are also conditioned on the character of operating FOEs. Low-industry FOEs tend to generate intra-sectoral spillovers, while high-tech ones inter-sectoral spillovers (Nicolini \& Resmini 2011a). However, when the technology gap between indigenous and foreign firms is narrow, FOEs generate competition effects rather than spillovers.

The spatial proximity of firms and individuals greatly facilitates the accumulation of knowledge and innovation, as well as the transfer of knowledge between economic entities in a particular location (Lundvall \& Johnson 1994). Ciccone \& Hall (1993) enu- merate three channels of spatial production density impact on labour productivity: (I) transport costs - concentration of economic activity reduces the average costs of providing products and services, (II) external effects related to the flow of technological knowledge, (III) effects related to the specialisation of production factors.

The concentration of production is also influenced by trade costs (Ottaviano \& Puga 1998). A high level of trade costs makes the flow of goods (trading) unprofitable, whereas low costs lead to agglomeration (Krugman \& Venables 1996). Thus, the improvement of the external (Baldwin et al. 2005) and internal accessibility of peripheral regions, swiftly became an instrument of regional policy attracting investors towards underdeveloped regions (McCann 2001). By improving the transport infrastructure, poor regions can influence the only fixed-to-the-region asset and increase their competitiveness (Gren 2003) through the reduction of transactional costs. As a result of increased revenues in a poor region and significant transport costs being present, manufacturers tend to locate in close proximity. The number of companies operating in poorer regions and benefiting from the development of the local market increases, which implies a reduction in the number of companies in a relatively richer region. The aforementioned dependencies cause a reduction in the agglomeration scale. However, with the inaccessibility of particular resources (like land), transport costs act as a centrifugal force, which counteracts the ongoing processes of agglomeration.

In the light of models of new trade theory and new economic geography, the tendency to agglomerate economic activity in a capitalrich region (Martin 1999; Fujita et al. 2001) is natural. In agglomeration regions, there are better incentives to acquire more specialised qualifications, which encourages companies to purchase more sophisticated equipment, thus the regions attract more specialist entities.

The New Economic Geography, initiated by Krugman (1991), has highlighted the need to simultaneously consider various factors 
affecting the development of regions. In the model of the core and periphery, the reasons for the division of the country into two-sector regions (industrialized centres and agricultural-based peripheries) were: the possibility of minimising transport costs (location closer to markets), economies of scale and spatial distribution of production (as a consequence of unequal occurrence of resources). These factors also determine the surge of interregional inequalities.

Among the causes of concentration of economic activity include those that remain exogenous to space and those of an endogenous nature. The sources of exogenous benefits do not refer to the category of external effects, but to aspects related to localization in space, which influence the minimization of transport costs, the proximity of natural resources, etc.

The endogenous benefits are divided into those: (I) resulting from economic specialization, and (II) resulting from the diversity of the economic structure. The former were called the Marshall-Arrow-Romer externalities (Glaeser et al. 1992), while the latter were named Jacobs' externalities (Jacobs 1969). The advantages of the Jacobs-type agglomeration externalities, in contrast to the MARtype, focus on the positive aspects related to the diversity of the economic structure. These benefits are then external to the economic sector, while endogenous to the analysed spatial layout (city, region, etc.) (Sokołowicz 2015). They occur when one type of economic activity increases the marginal productivity of other types of such activity due to their close location.

The privileges related to the benefits of the agglomeration will cause some companies from the peripheral regions to relocate their activities to richer regions. As the agglomeration process follows, the innovation rate of the economy increases and accelerated economic growth takes place. Nevertheless, not necessarily a large number of enterprises will be willing to relocate from a poorer region to a richer region if the transaction costs of intra-regional trade have been low so far. Other determinants, e.g. related to lower wages, may be more important than the benefits associated with agglomeration. The effect of lower wages may also enhance the relocation of labour-intensive branches from the richer to the poorer region. While poorer regions will specialize in labour-intensive industries, richer regions will attract industries requiring the high involvement of human and fixed capital (Martin 1998).

\section{Materials and methods}

The analysis was conducted on data on the number of firms with foreign capital (FOEs) registered in the REGON database in the years 1995-2017. Since it is the only publicly (and cost-free) available database on the location of FDI at low data aggregation level in Poland, the authors had to use the registry data. However, several issues with the database should be noted: (I) the location of a firm is assigned to its headquarters, which may result in a surplus number of entities, especially in large cities (like Warsaw); (II) in the event of several locations of a company (if the plants are located across the country) in most of the cases, only the company headquarters is visible in the registry, (III) potential surplus number of entities (in comparison to the operating entities). An additional source of data was obtained from calculations on maps (LAU 2) in the QGIS application, thanks to which the distances to regional capital cities were identified (in km). Similarly, other distance-based measures were obtained, such as: the distance to a special economic zone, the border, railway line, airport, seaport, etc. The other data were obtained from the Central Statistical Office in Poland, whereas most of computations were run in Stata 14.

The authors hypothesised that urbanisation is one of the important factors determining the spatial distribution of FOEs in Poland. Its positive verification could indicate that a greater number of firms with foreign capital in the county can be determined by their proximity to (large) cities (e.g. regional capitals). Since, FOEs may co-locate in places, where 
FOEs are already present, spatial interactions between gminas can explain a significant part of their locational behaviour, as firms may choose similar places to establish their businesses. With the use of spatial statistical and spatial econometric techniques, one can identify the scope of these associations and placement of FOEs hubs (gminas with a high concentration of FDI) as well as dwell on the extent of potential FDI spillovers generated from the hubs.

To depict the strength and direction of inter-gminas spatial dependence, the local and global measures of spatial autocorrelation are used. Following Anselin (1995), Moran's I global and local statistics were utilised. The former indicates the significance, strength and direction of the spatial association whereas the latter allows for the spatial identification of different gminas-specific patterns of spatial autocorrelation (the statistical interference of the level of similarity between neighbouring gminas). The spatial weight matrix $\mathrm{W}$ was determined on the basis of distance threshold of ca. $25 \mathrm{~km}^{1}$ and was later row-standardised. However, other approaches to establishing the $\mathrm{W}$ matrix were also tested (contiguity of the first order, second order, different distance thresholds) - they did not bring significant changes in the results.

The global index of Moran's I is described with the following equation:

$$
I_{w}=\frac{\sum_{i=1}^{n} \sum_{j=1}^{n} w_{i j}\left(x_{i}-\bar{x}\right)\left(x_{j}-\bar{x}\right)}{\sum_{i=1}^{n}\left(x_{i}-\bar{x}\right)^{2}}
$$

where:

$n$ - number of local area units,

$x$ - number of firms with foreign capital,

1 The study of Kopczewska (2013) indicates that municipalities located further than $25 \mathrm{~km}$ from regional capitals can be considered as peripheries, while their status does not change with longer distance from the core. The impact of local governments, according to the above study, is also limited to that distance threshold, implying positive institutional rent obtained to the distance of $25 \mathrm{~km}$. $w_{i j}$ - row-standardised spatial weights matrix,

$i^{\text {th }}$ - gmina,

$j^{\text {th }}$ - neighbouring gmina.

The statistics values range from -1 to 1 , where zero depicts a state of no spatial autocorrelation. Positive values indicate a positive autocorrelation, which denotes that local areas with a similar number of FDI are located close to each other, which will result in the formation of clusters. Negative values, signalling a negative autocorrelation, designate that local areas with different values are located nearby (it can be compared to a chessboard pattern).

Local Moran's I statistics are computed for every ith gmina in the dataset,

$$
I_{i}=\left(\frac{z_{i}}{m_{2}}\right) \sum_{j} w_{i j} z_{j}
$$

where:

$z_{i}, z_{j}$ - deviation from the mean of $i^{\text {th }}$ gmina or $j^{\text {th }}$ neighbouring gmina,

$m_{2}=\frac{\sum_{i} z_{i}^{2}}{N}$,

$w_{i j}$ - row-standardised spatial weights matrix.

Local Moran's I statistics FDI $i^{\text {th }}$ gmina takes one of five possible values:

- gminas with a high no. of FDI neighbouring with gminas also having a high no. of FDI (hot spot),

- gminas with a low no. of FDI neighbouring with gminas anticipating low no. of FDI (cold spot),

- gminas with a high no. of FDI neighbouring with gminas having low no. of FDI (outlier)

- gminas with a low no. of FDI neighbouring with gminas having high values (outlier),

- gminas with insignificant spatial autocorrelation - their values are close to the mean.

The maps presenting local Moran's I statistics and the number of FOEs were obtained in the GeoDa software, without a distinction for city areas located within urban-rural gminas. 
Lastly, to identify the location factors of FOEs in Poland, the authors apply the spatial probit model on a cross-section dataset for 2017 year only (due to availability of GIS-based variables, referring to distances between gminas' centroids and particular points of interests or minimum distances to lines). The usage of the approach was stemming from the fact, that there is high probability that locational choices of FOEs in a particular location may be similar to the ones in nearby locations (other gminas). The non-spatial approach would assume the decisions were individual- or region-independent, whereas spatial models imply that locational decision was generated by spatially dependent processes (LeSage \& Pace 2009).

The dependent variable was the dummy indicating whether gmina has FDI or not, whereas independent variables were indicating distances to: airport, border, national road, seaport, railway line, regional capital, as well as socio-economic-related variables: population per $1 \mathrm{~km}^{2}$, number of firms, Herfindahl-Hirschman Index $(\mathrm{HHI})$ of sectoral concentration of firms.

\section{Spatial agglomeration of foreign direct investment in Poland}

Between 1995 and 2017, one could observe a rapid increase in the number of FOEs operating in Poland. Foreign investors in most of the cases preferred city locations over the rural areas (Tab. 1). The role of cities was enforced by the high contribution of urban gminas and cities within urban-rural areas, constituting for more than $85 \%$ of the FOEs total locations in 2017. However, the in-time analysis reveals a decreasing role of city areas, as compared to 1995 , over the rural areas, which may signal positive effects of regional policy, tax incentives in SEZs, improvements in infrastructure endowments or changes in the location criteria of FOEs.

Given the high importance of city areas, one may ask about its impact on the loca- tion of FOEs. In fact, agglomeration seems to matter in terms of foreign-owned entities attraction. Large cities and metropolises, due to the concentration of the population, capital, firms, human capital, acquire more foreign entities. That is why the five biggest Polish cities: Warsaw, Kraków, Łódź, Wrocław, Poznań, are the main destinations of FOEs location $^{2}$ (Tab. 2). The role of the remaining cities is usually significantly smaller. Over the years 1995-2017, the contribution of cities sized 40k-99k and 20k-39k, has increased mostly, while the position of the largest has slightly decreased. Similarly to the abovementioned causes of changes in FOEs location patterns, one can add increasing costs due to congestion, observed in large cities, which can explain to some extent shifts in the contribution of particularly-sized cities.

The spatial distribution of FDI in Poland in 2017 was, to a high extent, associated with the role of metropolises or urban agglomerations, closeness to the western border as well as historical legacy. The highest number of firms with foreign capital was observed in Warsaw, Poznań, Tri-City, Katowice, Kraków, Wrocław, Szczecin, and its outskirts. Figure 1 presents the concentration of foreign-owned entities in absolute numbers (left panel) as well as in relative to $1 \mathrm{k}$ population (right panel). The role of big cities is acknowledged in both approaches, yet the main differences encompass the western border, which in the per capita version signals the role of proximity to the German border, where the highest contribution of Poland's exports is directed to.

The spatial inequalities in the operation of foreign-owned entities are not stable over time. Indeed, they upbuild in the study period, regardless of the used index, presenting the concentration of FOEs at the local level (Tab. 3). Not only have the mean number of entities increased, but also its second version (relative to population). Along with the positive upturn,

\footnotetext{
2 One has to remember the limitations stemming from the collection of statistical data in Poland that were described in the method section.
} 
Table 1. The composition of FOEs in Poland at commune level between 1995 and 2017

\begin{tabular}{|c|c|c|c|c|c|c|}
\hline \multirow{2}{*}{ Year } & $\begin{array}{c}\text { Total number } \\
\text { of FOEs } \\
\text { [entity] }\end{array}$ & $\begin{array}{c}\text { Urban com- } \\
\text { munes [\%] }\end{array}$ & $\begin{array}{c}\text { Rural com- } \\
\text { munes [\%] }\end{array}$ & $\begin{array}{c}\text { Urban-rural } \\
\text { communes [\%] }\end{array}$ & $\begin{array}{c}\text { Cities in urban- } \\
\text { rural communes } \\
\text { [pp.] }\end{array}$ & $\begin{array}{c}\text { Rural areas } \\
\text { in urban-rural com- } \\
\text { munes [pp.] }\end{array}$ \\
\hline 1995 & 31,156 & 85.80 & 6.09 & 8.11 & 5.63 & 2.48 \\
2000 & 55,961 & 83.41 & 7.41 & 9.17 & 6.23 & 2.92 \\
2005 & 54,185 & 77.60 & 10.41 & 11.99 & 7.92 & 4.07 \\
2010 & 68,219 & 77.34 & 11.29 & 11.37 & 7.45 & 3.92 \\
2015 & 85,257 & 78.63 & 11.13 & 10.24 & 6.57 & 3.67 \\
2016 & 90,766 & 79.11 & 10.93 & 9.96 & 6.35 & 3.61 \\
2017 & 94,516 & 79.56 & 10.60 & 9.84 & 6.28 & 3.56 \\
\hline
\end{tabular}

Source: own calculations in STATA 14.

Table 2. The share of total FOEs' establishments in Polish cities [\%]

\begin{tabular}{|c|c|c|c|c|c|c|c|}
\hline Cities' population & 1995 & 2000 & 2005 & 2010 & 2015 & 2016 & 2017 \\
\hline above 500,000 & 57.52 & 54.88 & 48.77 & 50.76 & 53.73 & 54.33 & 54.88 \\
$200,000-500,000$ & 12.37 & 11.45 & 14.00 & 13.66 & 12.97 & 12.88 & 12.96 \\
$100,000-199,999$ & 8.31 & 9.57 & 8.55 & 8.31 & 8.33 & 8.33 & 8.06 \\
$40,000-99,999$ & 8.15 & 8.57 & 10.10 & 9.65 & 9.19 & 9.25 & 9.20 \\
$20,000-39,999$ & 7.35 & 8.12 & 9.18 & 9.23 & 8.60 & 8.05 & 8.23 \\
$10,000-19,999$ & 4.56 & 5.20 & 6.46 & 5.82 & 4.97 & 5.02 & 4.63 \\
$5,000-9,999$ & 1.46 & 1.83 & 2.46 & 2.16 & 1.79 & 1.73 & 1.61 \\
$2,500-4,999$ & 0.27 & 0.36 & 0.47 & 0.39 & 0.41 & 0.40 & 0.41 \\
below 2,500 & 0.01 & 0.02 & 0.02 & 0.02 & 0.01 & 0.01 & 0.01 \\
\hline
\end{tabular}

Source: own calculations in STATA 14.

Information: In 2017 cities have attracted $85.84 \%$ of the total no. of foreign entities in Poland. The Table presents the sum of foreign-owned entities that were established in cities of particular size.

Table 3. Mean number and concentration of FOEs in Poland between 1995 and 2017

\begin{tabular}{|c|ccc|ccc|}
\hline \multirow{2}{*}{ Year } & \multicolumn{3}{|c|}{ Number of FOEs } & \multicolumn{3}{|c|}{ FOEs per thousand inhabitants } \\
\cline { 2 - 7 } & Mean & CV & HHI & Mean & CV & HHI \\
\hline 1995 & 14.69 & 14.20 & 0.096 & 0.28 & 1.88 & 0.002 \\
2000 & 26.27 & 13.33 & 0.084 & 0.57 & 1.87 & 0.002 \\
2005 & 25.57 & 13.94 & 0.092 & 0.69 & 1.77 & 0.002 \\
2010 & 32.16 & 14.47 & 0.099 & 0.80 & 2.34 & 0.003 \\
2015 & 40.22 & 15.39 & 0.112 & 0.91 & 2.66 & 0.004 \\
2016 & 42.81 & 15.49 & 0.114 & 0.94 & 2.73 & 0.004 \\
2017 & 44.58 & 15.62 & 0.116 & 0.95 & 2.69 & 0.004 \\
\hline
\end{tabular}

Source: own calculations in STATA 14.

Explanation: CV - coefficient of variation, $\mathrm{HHI}$ - Herfindahl-Hirschman Index. 


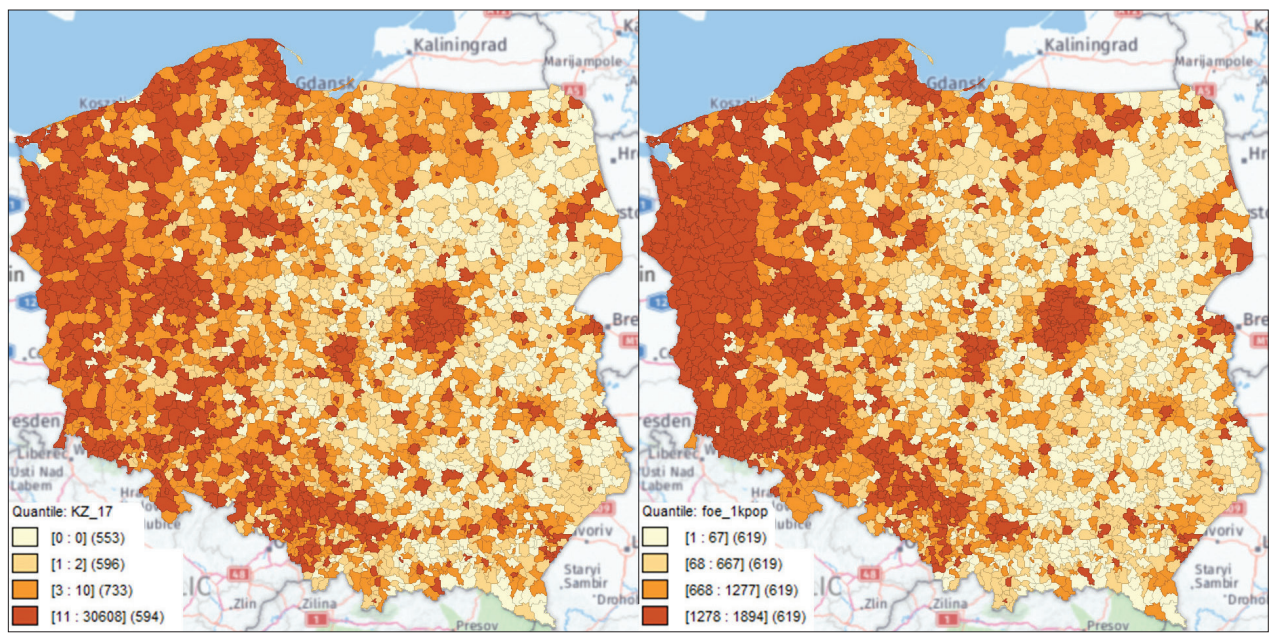

Figure 1. Number of FOEs in 2017 (left panel) and FOEs per thousand population (right panel)

Note: The first class in each of the cases represents the group of municipalities without FOEs.

the concentration (measured with $\mathrm{HHI}$ index) as well as the level of inequalities ( $C V$ index) have also grown, implying higher differences in the axis: centres vs. peripheries.

To examine the arising issue of uneven distribution of FOEs in more detail, the paper proceeds with the evaluation of local indices of I Moran's statistics. Its application enabled the identification of areas with similar number of FOEs that cluster spatially. By identifying the location of potential hubs, interconnected with the particular number of FOEs, the authors depicted local spikes, where foreign-owned entities concentrates in economic space as well as deprived areas, where FOEs are usually not willing to operate in.

In most of these cases, core-city areas were surrounded by conterminous gminas (also) with a high number of FDI, implying positive externalities generated by the cores, stemming from a positive and significant spatial autocorrelation (Fig. 2, left panel, red areas). While the distance from the core increases in particular cities (Warsaw, Tri-City, Szczecin, Łódź, Poznań, Kraków, Katowice), the autocorrelation pattern changes. These areas - marked with a light blue colour, indicate gminas with a low number of FDI, in vicinity of gminas with a high number of FDI. In this case, these areas may indicate outer zones of potential influence of the core cities to their surroundings.

However, not all of the regional capitals seemed to have enough 'size' (i.e. population) to significantly affect the neighbouring areas. Most of the regional capitals of Eastern Poland together with Opole, Zielona Góra, Toruń and Gorzów Wielkopolski were subjects of these instances. Often, in these cases, the area around the city was enveloped with not significant spatial autocorrelation pattern.

One of the major factors differentiating socio-economic space in Poland is also its history, which is still noticeable in many areas of the economy and socio-economic indicators. A significant east-west divide in terms of the number of FDI is apparent, being influenced by, i.e. an unequal level of economic development, the quality of infrastructure, level of entrepreneurship, quality of education, etc. These inequalities, to some extent, can be associated with differences that were present in the past in Poland, further magnified in the times of annexation and are still present (Zarycki 2007). They can affect, i.e. the current intensity of trade relations among regions (Brodzicki \& Uminski 2017).

Areas of Eastern Poland that can be especially linked to the Russian annexation (associ- 


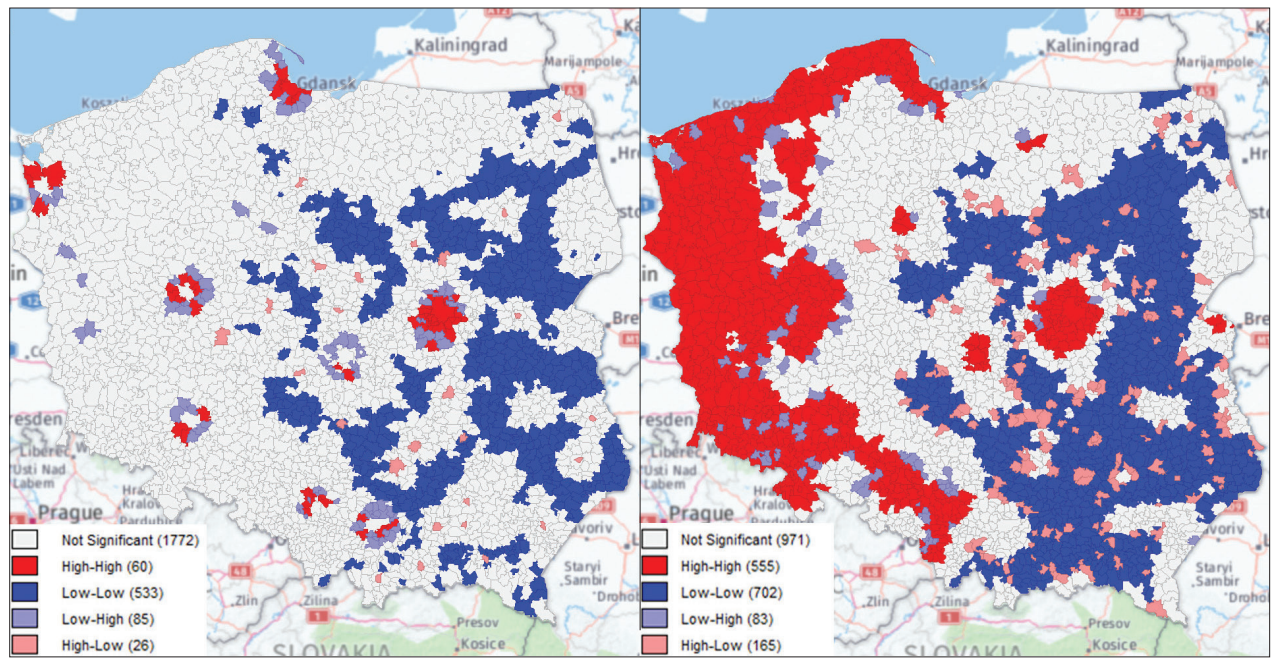

Figure 2. Agglomeration of FOEs in 2017 (left panel) and FOEs per thousand population in 2017 (right panel)

ated with the least-developed economies) and to a lesser extent to the Austrian annexation were described by a negative spatial autocorrelation (dark blue colour). The areas with a low no. of entities with foreign capital tended to be in close proximity to other local areas with similar characteristics, which produced the emergence of clusters. The low attractiveness for the FDI location (in most of the cases) was a result of poor infrastructure/labour endowment, low level of economic development and the distance to the EU markets.

Furthermore, the tendency of clustering FDI observed in specific regions in 1995 as compared to 2017 has increased, signalled by the I Moran global statistics. Its value has almost doubled between 1995 (0.0066) and 2017 (0.01273), indicating a surge in the role of spatial autocorrelation, which resulted in the higher intensity of spatial clustering of FOEs in nearby regions.

The changes in the number of FDI entities in gminas were to a high degree spatially concentrated in similar locations as in the case of the absolute number of firms with foreign capital (they are not presented due to almost identical results that of figure 2, left panel, but are available upon request). That is why, the observed patterns have resulted in an increase in inequalities between the loca- tion of FDI among Polish gminas. Two dimensions of these inequalities were observed: (I) east vs. west, and (II) metropolises vs. rest of the country. The former corresponds to the rapid growth of the metropolises in Poland and its role in the modern economy, whereas the latter refer to everlasting differentiation of Polish economic space that cannot be easily equalized.

These inequalities are even more visible when a different variable - foreign-owned entities per thousand population - is investigated (Fig. 2, right panel). The Moran's clustermap forms in this case vast clusters: (I) with high per capita concentration of FOEs (in particular municipalities and their surroundings) ranging from Katowice, through Wrocław, Legnica, Poznań, Gorzów Wielkopolski, Szczecin, Koszalin, Tri-City plus few 'islands' (Warsaw, Łódź, neighbourhood of Bydgoszcz, Olsztyn, Biała Podlaska), (II) low per capita number of FOEs in municipalities and their surroundings covering most of the Eastern Poland (with exception for WarmińskoMazurskie voivodship) and two other regions: Łódzkie, Mazowieckie (without the capital city area). The obtained results acknowledge the existing east-west diversification in Poland, that persist even today in many areas of economic geography of Poland also signalling the 
importance of the Western border or closeness to the EU markets. The remaining outlier areas of: (I) relatively low no. of FOEs per thousand population located in close proximity to high concentration of FOEs thereof, (II) high values compared to the neighbourhood, are respectively located close to the high-high clusters or scattered throughout economic space, implying positive role of particular small or medium-sized cities thereof.

Knowing the importance of spatial associations among gminas with respect to FOEs agglomeration, in the final part of the study, the authors investigated selected locational criteria of FOEs with the use of spatial probit models. Positive and statistically significant rho values, indicated moderate spatial autocorrelation in the dataset, indicating that an increase in FOEs number in a particular gmina leads to an increase in the number of FOEs in neighbouring gminas. The log-likelihood was compared to a-spatial models, but was in favour of SAR models. Thus, the application of spatial model was a legitimate choice.
According to obtained results, proximity to infrastructural endowments matters. Gminas located closer to national roads, railway lines, airports, seaports encountered higher probability of attracting foreign-owned entities (Tab. 4, column 1). Similar advantage possessed gminas located closer to external markets (the border), owing to mostly internationally-oriented strategy of FOEs operation (Nazarczuk \& Umiński 2018b).

Tax privileges, offered in special economic zones seemed to also positively affect FOEs decisions. However, their significance decreases as more economic variables is introduced into the model, what may imply their lesser role in attracting FOEs or the fact that they are at least further-ordered on the list of FOEs locational criteria.

The role of cities is introduced in two ways, as a distance to regional capital city (Tab. 4, column 1) or as population per 1 $\mathrm{km}^{2}$ (Tab. 4, columns 2-3). Both approaches, yielded in positive and significant estimates, indicating higher probability of locating

Table 4. Locational criteria of foreign-owned entities in Poland

\begin{tabular}{|c|c|c|c|}
\hline Variables & 1 & 2 & 3 \\
\hline Intercept & $1.6478^{\star \star \star}$ & $1.4816^{\star \star \star}$ & $2.294^{\star \star \star}$ \\
\hline SEZ (dummy variable) & $0.8459^{\star \star \star}$ & $0.4235^{\star \star \star}$ & $0.2711^{\star}$ \\
\hline Distance to airport & $-0.0011^{\star \star \star}$ & -0.0011 & -0.001 \\
\hline Distance to border & $-0.0022^{\star \star \star}$ & $-0.0024^{\star \star \star}$ & $-0.0027^{\star \star \star}$ \\
\hline Distance to national road & $-0.0186^{\star \star \star}$ & $-0.0124^{\star \star}$ & $-0.0057^{\star}$ \\
\hline Distance to seaport & $-0.0012^{\star \star \star}$ & $-0.0017^{\star \star \star}$ & $-0.0021^{\star \star \star}$ \\
\hline Distance to railway line & $-0.0314^{\star \star \star}$ & $-0.0288^{\star \star \star}$ & $-0.0236^{\star \star \star}$ \\
\hline Distance to regional capital city & $-0.0019^{\star \star \star}$ & & \\
\hline Population per km² & & $0.0016^{\star \star \star}$ & $0.0008^{\star}$ \\
\hline No. of firms & & $0.0003^{\star \star}$ & $0.0003^{\star \star}$ \\
\hline $\mathrm{HHI}$ of firms' sectoral concentration & & & $-0.0005^{\star \star \star}$ \\
\hline rho & $0.4015^{\star \star \star}$ & $0.1957^{\star \star}$ & $0.138^{\star}$ \\
\hline Log-likelihood & -1120.172 & -1044.028 & -1010.29 \\
\hline $\mathrm{R}^{2}$ & 0.7807 & 0.7952 & 0.7944 \\
\hline
\end{tabular}

Coefficients are presented. ${ }^{\star \star \star} p<0.01,{ }^{\star \star} p<0.05,{ }^{\star} p<0.1$ 
FOEs close to large regional capitals as well as their tendency to operate in urbanised areas. To some extent, FOEs were also attracted by general firms' concentration (Tab. 4, column 2) and firms' sectoral variety (column 3), usually observed in (larger) cities. Thus, the findings acknowledge the hypothesis on the role of urbanisation in the spatial agglomeration of FOEs in Poland.

\section{Conclusion and discussion of the findings}

The aim of the paper was to investigate the spatial distribution of FDI, including determinants of their location. According to the presented data, urbanisation was a significant factor describing the spatial agglomeration of FDI in Poland. However, the effect of agglomeration was uneven itself. The metropolises and large urban agglomerations attracted the majority of FOEs operating in Poland and had the most widespread outskirts with a similar core number of FDI, whereas small and medium-sized cities had, in most cases, a significantly lower no. of FDI in the neighbouring areas. The reason for this situation may be the fact that smaller cities did not have enough 'size' to initialise positive externalities to the neighbouring areas as compared to metropolises.

In this respect, the current findings acknowledge the results obtained by Zdanowska (2017), signalling the relative importance of other urban areas apart from the capital city in Poland as compared to other CEEC countries. The results of Nazarczuk \& Umiński (2018a) for the participation of FOEs in total local exports of Poland (at LAU 1 level, Polish: powiats), fit into the regularities observed in this study, also implying the concentration of FOEs activity (in exports) closer to the western border or larger cities. The findings are also in line with Wu \& Radbone (2005) in identifying the role of openness and general development level as a stimuli for FDI inflow at an urban level. Furthermore, the above-mentioned authors, based on the example of Shenzen, identify the positive role of tax incentives, granted to manufacturing $\mathrm{FDI}$ as well as the role of service FDI concentration as a pull factor for FDI in services. Unfortunately, the unavailability of the data for sectoral-level FDI for Poland, has restricted the analysis to the overall no. of FDI and significantly reduced the list of available variables (e.g. quality of human capital). One has to remember that the analysis of location determinants was run for the 2017 year only. The usage of spatial panelling techniques, coupled with causality tests, could result in more robust findings, also presenting the particular variables' direction of influence on FOEs attraction.

The remaining question is: to what extent can local authorities interfere in the observed tendencies, especially in the lagging areas in order to enhance their abilities to absorb foreign capital and create new workplaces, which may improve the economic situation of (at least some) local areas. The role of sufficient quantity and good quality of inputs seems to be crucial. Therefore, local authorities should try to contribute to the improvement of human capital, their competences as well as adjust the vocational education programmes to fit the investors' needs. However, these may be not enough, since investors also look for well-developed transportation infrastructure and proximity to (in many cases distant) markets. However, for some of them Poland may be the destination market. Everything depends on the strategy adopted by multinationals and the primary goal in the search for location.

Since the area location is fixed, the local authorities try to compete for investments with the use of different incentives. One of them is the location of subzones within special economic zones, providing profit tax exemptions for entities with a valid permit to operate within the zones. By delegating extra local tax exemptions to local authorities (like property tax) they try to attract the FDI on their grounds. However, the effectiveness of tax incentives is often controversial, due to the high dispersion of location of SEZs 
in Poland. For many, FDI tax exemption is an important locational factor, but not crucial in undertaking locational decisions (other local authorities also grant similar incentives), therefore it is a blunt instrument in enhancing FDI inflow at a local level. Additionally, the positive effects of SEZs operation are usually observed only in weaker regions of Poland (Ambroziak \& Hartwell 2017).

Finally, as proposed by the Ministry of Development, the extension of the territory of SEZ to the whole area of Poland (not only in designated places, usually with the accumulation of structural issues) may solidify the existing inequalities in the FDI statistics, due to more frequent locations offering better input endowment, coupled with superior transport infrastructure, as well as a convenient location close to EU markets.

However, since the long term sustainable growth effect of FDI is frequently questionable in less developed economies (Gal \& Schmidt 2017), local authorities should not rely their growth policy on FDI inflow or FOEs activity only, nor should they consider FOEs as a panacea for their development problems. Owing to the frequent failure to achieve substantial spillovers from FOEs to indigenous

\section{References}

Ambroziak A.A., Hartwell C.A., 2017. The impact of investments in special economic zones on regional development. The case of Poland. Regional studies, vol. 52, no. 10, pp. 1322-1331.

ANSELIN L., 1995. Local indicators of spatial association-LISA. Geographical Analysis, vol. 27, no. 2, pp. 93-115.

ArRow K.J., 1962. Economic welfare and the allocation of resources for invention [in:] N.B.o.E. Researc (ed.), The Rate and Direction of Inventive Activity, Princeton: Princeton University Press.

AudReTSCH B., 1998. Agglomeration and the location of innovative activity. Oxford Review of Economic Policy, vol. 14, no. 2, pp. 18-29. sectors, their influence is frequently limited to the local economies, as they rarely cooperate with local suppliers. These spillovers are in many cases conditioned on the quality of informal institutions or more broadly social capital (Casi \& Resmini 2017). Given the lack of embeddedness in FOEs operation, a better policy approach might be undertaking actions towards facilitation of domestic capital (SME or large entities) and fostering innovation.

\section{Acknowledgements}

We would like to thank two anonymous reviewers for helpful comments to the first version of the paper. The usual disclaimer applies. The data used in this article were obtained within the project entitled "Foreign Trade in Special Economic Zones in Poland", financed from the National Science Centre in Poland (grant decision number: DEC2013/11/D/HS4/04007).

Editors' note:

Unless otherwise stated, the sources of tables and figures are the authors', on the basis of their own research.

Baldwin R., Forslid R., Martin P., 2005. Economic geography and public policy. Princeton University Press.

BRODZICKI T., UMINSKI S., 2017. A gravity panel data analysis of foreign trade by regions. The role of metropolises and history. Regional studies, vol. 11, no. 1, pp. 1-13.

BRONZINI R., 2007. FDI inflows, Agglomeration and host country firms' size. Evidence from Italy. Regional studies, vol. 41, no. 7, pp. 963-978.

CASI L., ResminI L., 2014. Spatial complexity and interactions in the FDl attractiveness of regions. Papers in Regional Science, vol. 93, S51-S78.

CASI L., RESMINI L., 2017. Foreign direct investment and growth. Can different regional identities shape the returns to foreign capital investments? Environment and Planning C: Politics and Space, vol. 35, no. 8, pp. 1483-1508. 
Chidlow A., Salciuviene L., Young S., 2009. Regional determinants of inward FDI distribution in Poland. International Business Review, vol. 18, no. 2, pp. 119-133.

Ciccone A., Hall R., 1993. Productivity and the density of economic activity. Cambridge, MA: National Bureau of Economic Research.

CieślIK A., 2005a. Geografia inwestycji zagranicznych: przyczyny i skutki lokalizacji spółek z udziałem kapitału zagranicznego w Polsce. Warszawa: Wydawnictwa Uniwersytetu Warszawskiego.

CIEŚLIK A., 2005b. Location of foreign firms and national border effects. The Case of Poland. Tijdschrift voor Economische en Sociale Geografie, vol. 96, no. 3, pp. 287-297.

CieśLIK A., 2005c. Regional characteristics and the location of foreign firms within Poland. Applied Economics, vol. 37, no. 8, pp. 863-874.

CIEŚLIKA., 2007. Czynniki lokalizacji spółek z udziałem kapitału zagranicznego w Polsce. Gospodarka Narodowa, vol. 18, no. 3, pp. 25-48.

CIEśLIK A., 2013. Determinants of the location of foreign firms in Polish regions. Does firm size matter? Tijdschrift voor economische en sociale geografie, vol. 104, no. 2, pp. 175-193.

Cieślik A., Ryan M., 2005. Location determinants of Japanese multinationals in Poland. Do special economic zones really matter for investment decisions? Journal of Economic Integration, vol. 20, no. 3, pp. 475-496.

Crozet M., Mayer T., Mucchielli J.-L., 2004. How do firms agglomerate? A study of FDI in France. Regional Science and Urban Economics, vol. 34, no. 1, pp. 27-54.

Domański B., 2001. Kapitał zagraniczny w przemyśle Polski: prawidłowości rozmieszczenia, uwarunkowania i skutki. Kraków: Instytut Geografii i Gospodarki Przestrzennej Uniwersytetu Jagiellońskiego.

Du J., LU Y., TAO Z., 2008. FDI location choice. Agglomeration vs institutions. International Journal of Finance \& Economics, vol. 13, no. 1, pp. 92-107.

Fujita M., Krugman P.R., Venables A.J., 2001. The spatial economy. Cities, regions, and international trade. Inglaterra: MIT Press.

FUIITA M., THISSE J.-F., 2013. Economics of agglomeration. Cities, industrial location, and globalization. New York: Cambridge University Press.
Gal Z., Schmidt A., 2017. Geoeconomics in Central and Eastern Europe [in:] J.M. Munoz (ed.), Advances in geoeconomics. Europa economic perspectives, London-New York: Routledge.

Glaeser E.L., Kallal H.D., Scheinkman J.A., ShleifER A., 1992. Growth in cities. Journal of Political Economy, vol. 100, no. 6, pp. 1126-1152.

GREN J., 2003. Reaching the peripheral regional growth centres. European Journal of Spatial Development, vol. 3, pp. 1-22.

Hoover E.M., 1936. The measurement of industrial localization. The Review of Economics and Statistics, pp. 162-171.

JACOBS J., 1969. The economy of cities. New York: Vintage.

Kisiel R., Krajewska A., Nazarczuk J.M., 2017. Spatial concentration of businesses with foreign capital in the capital cities of the Polish voivodeships and their agglomerations from 1995-2016. Acta Scientiarum Polonorum-Oeconomia, vol. 16, no. 4, pp. 71-81.

KopCZEWSKA K., 2013. The spatial range of local governments. Does geographical distance affect governance and public service? The Annals of Regional Science, vol. 51, no. 3, pp. 793-810.

Krugman P., 1991. Increasing returns and Economic Geography. Journal of Political Economy, vol. 99, no. 3, pp. 483-499.

Krugman P., Venables A.J., 1996. Integration, specialization, and adjustment. European Economic Review, vol. 40, no. 3-5, pp. 959-967.

LATOCHA T., 2002. Lokalizacja produkcji międzynarodowej a procesy integracji europejskiej. Studia Europejskie/Centrum Europejskie Uniwersytetu Warszawskiego, no. 3, pp. 73-90.

LeSage J., Pace P., 2009. Introduction to spatial econometrics. Statistics, Textbooks and Monographs, Boca Raton-London-New York: CRC Press.

Lundvall B.-̈̈., Johnson B., 1994. The learning economy. Journal of industry studies, vol. 1, no. 2, pp. 23-42.

Marshall A., 1920. Principles of Economics. London: MacMillan.

Martin P., 1998. Can regional policies affect growth and geography in Europe? The World Economy, vol. 21, no. 6, pp. 757-774. 
MARTIN P., 1999. Are European regional policies delivering? ElB Papers, vol. 4, no. 2, pp. 10-23.

McCann P., 2001. Urban and regional economics. New York: Oxford University Press.

NazArCzUK J.M., 2013. Potencjał rozwojowy a aktywność inwestycyjna województw i podregionów Polski. Olsztyn: Wydawnictwo Uniwersytetu Warmińsko-Mazurskiego.

NAZARCZUK J.M., 2015. Regional distance. The concept and empirical evidence from Poland. Bulletin of Geography. Socio-economic series, vol. 28, no. 28, pp. 129-141.

Nazarczuk J.M., Krajewska A., 2018. Local determinants of foreign direct investment in Poland. The role of relative distance. Equilibrium, vol. 13, no. 1, pp. 73-88.

NAZARCZUK J.M., UMIŃSKI S., 2018a. The geography of openness to foreign trade in Poland: The role of special economic zones and foreignowned entities. Bulletin of Geography. Socioeconomic series, no. 38, pp. 97-111.

NAZARCZUK J.M., UmIŃSKI S., 2018b. The impact of special economic zones on export behaviour. Evidence from Polish firm-level data. E+M Ekonomie a Management, vol. 21, no. 3, pp. 4-22.

Nicolini M., ResminI L., 2011a. FDI spillovers in new EU member states. Economics of Transition, vol. 18, no. 3, pp. 487-511.

NicolinI M., ResminI L., 2011b. Productivity spillovers, regional spillovers and the role of by multinational enterprises in the new EU Member States [in:] K. Kourtit, P. Nijkamp, R. Stough (eds.), Drivers of innovation, entrepreneurship and regional dynamics. Advances in spatial science, Berlin-Heidelberg-New York: Springer, pp. 105-120.

OECD, 2010. Regional development policies in OECD countries. OECD Publishing.

Ottaviano G.I.P., 2011. 'New' new economic geography. Firm heterogeneity and agglomeration economies. Journal of Economic Geography, vol. 11, no. 2, pp. 231-240.

Ottaviano G.I.P., Puga D., 1998. Agglomeration in the global economy. A survey of the 'new economic geography'. The World Economy, vol. 21, no. 6, pp. 707-731.
OtTAVIANo G.I.P., THISSE J.-F., 2005. New economic geography. What about the N? Environment and Planning A, vol. 37, no. 10, pp. 1707-1725.

RESMINI L., 2007. The determinants of FDI in Central, Eastern and South-Eastern Europe. Lessons from the past and prospects for the future [in:] K. Liebscher, J. Christl, P. Mooslechner, D. Ritzberger-Grünwald (eds.), Foreign Direct Investment in Europe: A changing landscape. Cheltenham: Edward Elgar Publishing, pp. 207-226.

RESMINI L., 2013. FDI in services in European regions. An overview [in:] J.R. Cuadrado-Roura (ed.), Service Industries and Regions: Growth, Location and Regional Effects, Berlin-Heidelberg: Springer, pp. 159-176.

ROUBíČKOVÁ M., HeRYÁN T., 2014. Impacts of selected NACE industries' foreign ownership on the Czech economy. E+M Ekonomie a Management, vol. 17, no. 4, pp. 58-69.

Sokołowicz M.E., 2015. Rozwój terytorialny w świetle dorobku ekonomii instytucjonalnej: Przestrzeń - bliskość - instytucje. Łódź: Wydawnictwo Uniwersytetu Łódzkiego.

UMIŃSKI S., 2012. Rozważania nad natura, przyczynami oraz konkurencyjnościq działalności eksportowej w ujęciu regionalnym dla Polski. Gdańsk: Wydawnictwo Uniwersytetu Gdańskiego.

Wu J., Radbone I., 2005. Global integration and the intra-urban determinants of foreign direct investment in Shanghai. Cities, vol. 22, no. 4, pp. 275-286.

ZARYCKI T., 2007. History and regional development. A controversy over the 'right' interpretation of the role of history in the development of the Polish regions. Geoforum, vol. 38, no. 3, pp. 485-493.

ZDANOWSKA N., 2017. Distribution of foreign direct investments across the national urban systems in countries of Central and Eastern Europe in 2013. Geographia Polonica, vol. 90, no. 2, pp. 5-24.
(C) Jarosław Michał Nazarczuk - Anna Krajewska

(C) Geographia Polonica

(C) Institute of Geography and Spatial Organization

Polish Academy of Sciences • Warsaw • 2018
Article first received • January 2018 Article accepted • October 2018 